\title{
Energy-saving ventilation system for sheep premises to ensure food security and safety
}

\author{
Muratbek ISSAKHANOV ${ }^{1 *}$ (D), Nessipbek ALIBEK ${ }^{1}$ (D), Turemurat DYUSENBAYEV ${ }^{1}$ (D), Aigul TALDYBAYEVA ${ }^{1}$ (D)
}

\begin{abstract}
The impact of stress on an animal's physiological and behavioral state and the final meat quality has been extensively established. Prior to slaughter, animals are usually denied food and drink to reduce stomach content and minimize contamination from gut contents spilling from unintentional punctures to the gastrointestinal system during the eviscerating procedure. Feed withholding offers the benefit of lowering consumption of food as well as morbidity and death rates while in transit. Food restriction, on the other hand, triggers a stress reaction and causes animals to lose weight. In sheep farming, ventilation systems that functioned at temperatures above the threshold air temperature and relative humidity were very efficient and productive. The ventilation system proposed here works by using soil warmth, i.e., a renewable source of energy, and contributes to environmental protection. The results of theoretical and experimental studies of an energy-saving ventilation system using soil heat are presented. The use of an energy-saving ventilation system reduces energy and labor costs for creating a microclimate in sheep premises. The device of an energy-saving ventilation system is protected by the patent of RK KZ 26930 dated 15.07.2016.
\end{abstract}

Keywords: food security and safety; underground heat exchanger; air duct; soil heat.

Practical application: It is used to create a microclimate in a sheep-breeding room.

\section{Introduction}

Sheep are a vital source of income for local farmers and landless people in rural areas. It emphasizes the possible influence of sheep ranching management on food security and safety concerns in particular areas (Rice et al., 2020; Soni et al., 2021; Warriss, 2020). The significant connection of sheep with the environment in rural and extended agricultural systems renders sediments, air, and environmental quality of soils connected to water supply a critical component in ensuring a secure and safe alimentary intake of sheep-derived foods. Food derived from animals is the primary source of exposure for the common people to persistent organic pollutants, including polychlorobiphenyls and dioxins, as defined by the Stockholm Convention, which was developed with the UN Environment Program's assistance (Grandin, 2021; Leonte \& Leonte, 2020; Onopiuk et al., 2021). The muscles of animals (as well as humans) contain a sugar called glycogen, which is converted to lactic acid after death. This is what makes meat crispy, tasty, and also resistant to bacteria. When an animal is stressed, for example, scared, tired, or sick, muscle glycogen levels drop and it is spent on metabolism, energy supply, and coping with stress. Therefore, the lactic acid level of this animal after slaughter is significantly lower than other healthy animals. This is the same change that occurs in the slaughter of old and malnourished animals, malnourished animals, sick animals, high stress of animals slaughtered at home, and violent treatment of animals before slaughter or harassment. Furthermore, recent research has discovered that food restriction has relatively little influence on meat quality characteristics (Table 1) (Baljić et al., 2019; Costa et al., 2020; Gali et al., 2020; Stahlke et al., 2019).
Rational use of fuel and energy resources is one of the world's global problems today. One of the promising ways to solve this problem is the use of new energy-saving technologies using non-traditional renewable energy sources (Ponnampalam et al., 2020; Tsakiridis et al., 2020). The range of renewable energy sources applications on farms is quite wide: this includes heating or cooling buildings, drying agricultural products, desalination or heating water, and even autonomous energy supply.

The advantages of such energy sources are environmental cleanliness and low labor and money costs for the operation of installations for their use. The solution to the problem of energy saving in agricultural ventilation systems is the effective use of low-potential soil heat (Phillips, 2019). The soil of the surface layers of the Earth is actually a thermal accumulator of unlimited capacity, the thermal regime of which is formed under the influence of solar radiation. The low-potential heat of the Earth can be used in agricultural premises for heating, hot water supply, air conditioning (cooling) (Nenadović et al., 2021).

There are a number of examples of the use of soil heat for heating and cooling livestock premises through underground air ducts and heat exchangers. They have saved from $50 \%$ to $75 \%$ of the cost of heating and cooling the premises. The study of these examples allowed to development of an energy-saving ventilation system for sheep premises (Ibidhi \& Salem, 2019; Moberg et al., 2021). Figure 1 shows the functional scheme of the ventilation system; Figure 2 - section on A-A of Figure 1; Figure 3 - block scheme of the control of the electric motor and control valves of the supply air ducts and air funnel, spray, and closers. 
Table 1. The impact of pre-slaughter management on animal stress responses and meat quality characteristics has recently been published.

\begin{tabular}{|c|c|c|c|c|}
\hline Factor & Carcass and meat quality traits & Stress responses & Species & Pre slaughter handling conditions \\
\hline \multirow[t]{3}{*}{ Food/water deprivation } & $\begin{array}{l}12 \text { and } 24 \mathrm{~h} \text { food deprivation } \\
\text { increased muscle } \mathrm{pH}_{3 \mathrm{~h}} \text { and } \mathrm{pH}_{24} \\
\text {; sarcomere length increased at } \\
\text { postmortem } 0 \mathrm{~h} \text {, while decreased at } \\
\text { postmortem } 10 \mathrm{~h} \text { after } 24 \mathrm{~h} \text { fasting }\end{array}$ & $\begin{array}{l}24 \mathrm{~h} \text { food deprivation increased } \\
\text { plasma corticosterone level }\end{array}$ & Poultry & 0,12 , and $24 \mathrm{~h}$ food deprivation \\
\hline & $\begin{array}{l}\text { Pigs deprived of food for } 24 \mathrm{~h} \\
\text { had lower carcass dressing yield; } \\
14 \text { and } 24 \text { h food deprivation } \\
\text { increased carcass bruise score; food } \\
\text { deprivation had limited effects on } \\
\text { meat quality traits }\end{array}$ & $\begin{array}{l}14 \mathrm{~h} \text { food deprivation-induced the } \\
\text { highest urinary cortisol level }\end{array}$ & Pigs & 4,14 , and $24 \mathrm{~h}$ food deprivation \\
\hline & $\begin{array}{c}\text { Water deprivation caused an } \\
\text { increase in live weight loss; water } \\
\text { deprivation decreased drip loss, } \\
\text { cooking loss, } L^{*}, b^{*} \text {, and ultimate } \mathrm{pH}\end{array}$ & $\begin{array}{l}\text { Water deprivation increased urea, } \\
\text { creatinine, and muscle supernatant } \\
\text { osmolality }\end{array}$ & Sheep & $\begin{array}{l}48 \mathrm{~h} \text { water deprivation or not } \\
\text { under normal or high ambient air } \\
\text { temperature }\end{array}$ \\
\hline \multirow[t]{3}{*}{ Transport } & $\begin{array}{l}\text { Transport decreased live body } \\
\text { weight; transport increased } \\
\text { ultimate } \mathrm{pH} \text { and shear force value, } \\
\text { while decreased expressed juice, } \\
\text { cooking loss, sarcomere length, and } \\
\text { meat color }\left(L^{*}, a^{*} \text {, and } b^{*}\right) \text { values }\end{array}$ & $\begin{array}{c}\text { Transport increased plasma } \\
\text { cortisol, dopamine, adrenaline, and } \\
\text { noradrenaline levels }\end{array}$ & Sheep & $\begin{array}{l}48 \mathrm{~h} \text { lairage with ad libitum feed } \\
\text { and water as a not-transported } \\
\text { group; } 2 \mathrm{~h} \text { preslaughter transport } \\
\text { under high temperature }\left(37.5^{\circ} \mathrm{C}\right) \\
\text { as transported group }\end{array}$ \\
\hline & $\begin{array}{c}\text { Transport time significantly } \\
\text { affected drip loss, pH, and meat } \\
\text { color }\end{array}$ & $\begin{array}{c}3 \mathrm{~h} \text { transport elevated plasma } \\
\text { glucose and lactate levels; } 5 \mathrm{~h} \\
\text { transport elevated plasma cortisol, } \\
\text { LDH, and glucose levels }\end{array}$ & Pigs & $\begin{array}{l}40 \text { min compared with } 3 \mathrm{~h} \\
\text { compared with } 5 \mathrm{~h} \text { transport }\end{array}$ \\
\hline & $\begin{array}{l}2 \mathrm{~h} \text { or longer transport caused the } \\
\text { morality of broilers; } 0.5 \text { h transport } \\
\text { decreased } \mathrm{pH} \text {, increased lightness, } \\
\text { drip loss, and cooking loss, } \\
\text { inducing PSE-like meat }\end{array}$ & $\begin{array}{c}\text { Transport increased plasma CK and } \\
\text { LDH levels }\end{array}$ & Poultry & $\begin{array}{c}\text { Unstressed control compared } \\
\text { with } 0.5 \mathrm{~h} \text { compared with } 1 \mathrm{~h} \\
\text { compared with } 2 \mathrm{~h} \text { compared with } \\
4 \text { h transport; high temperature }(40 \\
\left.\text { to } 42{ }^{\circ} \mathrm{C}\right)\end{array}$ \\
\hline \multirow[t]{3}{*}{ Lairage } & $\begin{array}{l}\text { Lairage increased weight losses; } 3 \\
\text { h lairage induced the highest } \mathrm{pH} \text {, } \\
\text { shear force, and toughness and } \\
\text { the lowest } b \text { and chroma values; } \\
3 \text { and } 6 \mathrm{~h} \text { lairage decreased WHC } \\
\text { at } 24 \mathrm{~h} \text { post mortem; the effects of } \\
\text { lairage time on texture and WHC } \\
\text { disappeared after } 5 \mathrm{~d} \text { storage }\end{array}$ & - & Sheep & $\begin{array}{l}1.5 \mathrm{~h} \text { preslaughter transport } \\
\text { followed by } 0,3,6 \text {, and } 12 \mathrm{~h} \text { lairage }\end{array}$ \\
\hline & $\begin{array}{c}1 \mathrm{~h} \text { rest reduced muscle } \\
\text { temperatures; } 3 \mathrm{~h} \text { rest normalized } \\
\text { early postmortem pH decline; } 1 \\
\text { or } 3 \mathrm{~h} \text { rest decreased drip loss and } \\
\text { extra-myofibrillar water; rest had } \\
\text { no effect on toughness }\end{array}$ & - & Pigs & $\begin{array}{c}\text { Treadmill exercise followed by } 0,1 \text {, } \\
\text { or } 3 \mathrm{~h} \text { rest }\end{array}$ \\
\hline & $\begin{array}{l}\text { Lairage decreased ultimate } \mathrm{pH} \text {; } \\
\text { Bulls subjected to } 24 \text { h lairage had } \\
\text { the lowest } L^{*}, b^{*} \text {, and } H^{*} \text { values; } \\
\text { lairage time had no effects on WHC, } \\
\text { cooking loss, and shear force values }\end{array}$ & - & Cattle & $\begin{array}{l}30 \mathrm{~h} \text { preslaughter transport } \\
\text { followed by } 24,48 \text {, and } 72 \mathrm{~h} \text { lairage }\end{array}$ \\
\hline \multirow[t]{2}{*}{ Transport and lairage } & $\begin{array}{l}\text { Transport, lairage, or transport } \times \\
\text { lairage had no effect on } \mathrm{pH} \text {, drip } \\
\text { loss, shear force, or meat color } \\
\text { (lightness) }\end{array}$ & $\begin{array}{l}3 \mathrm{~h} \text { lairage after transport restored } \\
\text { plasma corticosterone level; } 3 \mathrm{~h} \\
\text { transport induced glycopenia }\end{array}$ & Poultry & $\begin{array}{l}\text { Unstressed control compared with } \\
45 \text { min transport, } 45 \text { min lairage } \\
\text { compared with } 45 \text { min transport, } \\
3 \text { h lairage compared with } 3 \mathrm{~h} \\
\text { transport, } 45 \text { min lairage compared } \\
\text { with } 3 \text { h transport, } 3 \text { h lairage }\end{array}$ \\
\hline & $\begin{array}{l}\text { Sheep subjected to } 18 \mathrm{~h} \text { lairage } \\
\text { had the lowest preslaughter } \\
\text { live weight but the highest cold } \\
\text { carcass dressing percentage; Sheep } \\
\text { subjected to } 30 \text { min lairage after } \\
\text { transport showed lower cooking } \\
\text { loss and higher } \mathrm{pH}_{0}, \mathrm{pH}_{24 \mathrm{~h}} \text {, and } \\
\text { shear force value }\end{array}$ & $\begin{array}{l}\text { Transport increased plasma } \\
\text { cortisol, CK, LDH, and glucose } \\
\text { levels; } 18 \text { h lairage decreased CK, } \\
\text { LDH, and glucose levels }\end{array}$ & Sheep & $\begin{array}{l}75 \text { min transport, } 18 \mathrm{~h} \text { lairage } \\
\text { compared with } 75 \text { min transport, } \\
30 \text { min lairage compared with no } \\
\text { transport, } 30 \text { min lairage }\end{array}$ \\
\hline \multirow[t]{2}{*}{ Stunning } & $\begin{array}{l}\text { Head to brisket stunning increased } \\
\text { postmortem muscle pH decline } \\
\text { and induced paler meat with higher } \\
\text { drip loss; head only tongs and } \\
\mathrm{CO}_{2} \text { stunning improved carcass } \\
\text { quality }\end{array}$ & - & Pigs & $\begin{array}{c}\text { Gas stunning using } 90 \% \\
\mathrm{CO}_{2} \text { compared with head only } \\
\text { manual electrical stunning } \\
\text { compared with head to brisket } \\
\text { electrical stunning }\end{array}$ \\
\hline & $\begin{array}{l}\text { Gas stunning slowed down } \\
\text { postmortem pH decline; stunning } \\
\text { had significant effects on meat quality } \\
\text { traits (meat color, WHC, cooking } \\
\text { loss, and drip loss) at } 7 \mathrm{~d} \text { postmortem }\end{array}$ & - & Sheep & $\begin{array}{l}\text { Slaughtered without stunning } \\
\text { compared with electrically stunning } \\
\text { compared with gas stunning using } \\
90 \% \mathrm{CO}_{2}\end{array}$ \\
\hline
\end{tabular}


Table 1. Continued...

\begin{tabular}{|c|c|c|c|c|}
\hline Factor & Carcass and meat quality traits & Stress responses & Species & Pre slaughter handling conditions \\
\hline & $\begin{array}{l}\text { Stunning affected cooking loss, } \\
\text { color coordinates, and texture } \\
\text { parameters; the stunned percussive } \\
\text { group had better sensory attributes } \\
\text { (odor, flavor, tenderness, and } \\
\text { overall acceptability) than the non- } \\
\text { stunned group }\end{array}$ & - & Cattle & $\begin{array}{l}\text { None-stunning and slaughtered } \\
\text { under Turkish slaughter procedure } \\
\text { compared with electrically stunning } \\
\text { compared with percussive captive } \\
\text { bolt stunning }\end{array}$ \\
\hline & $\begin{array}{c}5 \mathrm{~V} \text { caused wing damage, } 45 \\
\mathrm{~V} \text { caused pectoralis major } \\
\text { and pectoralis minor damage; } \\
5 \mathrm{~V} \text { decreased muscle } \mathrm{pH}_{2} \\
\text { hostmortem; } 5 \text { and } 45 \mathrm{~V} \text { increased } \\
\text { drip loss and decreased shear force } \\
\text { value }\end{array}$ & $\begin{array}{l}5 \mathrm{~V} \text { stunning caused the highest } \\
\text { plasma corticosterone and lactate } \\
\text { levels }\end{array}$ & Poultry & $\begin{array}{l}\text { Electrical stunning with } 5,15,25 \text {, } \\
35 \text {, and } 45 \mathrm{~V} \text { at } 750 \mathrm{~Hz} \text { for } 10 \mathrm{~s}\end{array}$ \\
\hline & $\begin{array}{l}\text { Electrical stunning impaired breast } \\
\text { meat color by decreasing } a^{*} \text { at } 1,3 \text {, } \\
\text { and } 9 \text { d. } 150 \mathrm{~V}, 60 \mathrm{~Hz} \text { stunning } \\
\text { reduced lipid oxidation in breast } \\
\text { meat }\end{array}$ & $\begin{array}{c}65 \mathrm{~V}, 1000 \mathrm{~Hz} \text { stunning decreased } \\
\text { plasma triiodothyronine/thyroxine, } \\
\text { while increased corticosterone and } \\
\text { uric acid levels }\end{array}$ & Poultry & $\begin{array}{c}\text { Slaughtered without stunning } \\
\text { compared with electrical stunning } \\
\text { with } 65 \mathrm{~V}, 1000 \mathrm{~Hz} \text { compared } \\
\text { with electrical stunning with } 150 \\
\text { V, } 60 \mathrm{~Hz}\end{array}$ \\
\hline \multicolumn{5}{|l|}{ Other handling procedures } \\
\hline \multirow[t]{2}{*}{ Catching/loading } & $\begin{array}{l}\text { Loading method had no effects on } \\
\text { live weight and slaughter data of } \\
\text { rabbits; Rough loading increased } \\
\text { cooking loss while had no effects } \\
\text { on other meat quality traits }\end{array}$ & $\begin{array}{l}\text { Loading method had no effects on } \\
\text { hematological and biochemical } \\
\text { stress parameters }\end{array}$ & Rabbit & $\begin{array}{l}\text { Smooth (carefully place each } \\
\text { rabbit into the transport crates) } \\
\text { compared with rough (hurriedly } \\
\text { and carelessly throw each rabbit } \\
\text { into the crates) }\end{array}$ \\
\hline & $\begin{array}{l}\text { The catching method did not } \\
\text { influence the percentage of bruises } \\
\text { or meat quality }\end{array}$ & $\begin{array}{c}\text { Mechanical catching increased } \\
\text { dead-on-arrival rate and plasma } \\
\text { glucose level }\end{array}$ & Poultry & $\begin{array}{l}\text { Mechanical catching (catching } \\
\text { machine containing rotating, } \\
\text { hydraulically driven cylinders) } \\
\text { compared with manual catching } \\
\text { (professional catching teams) }\end{array}$ \\
\hline \multirow[t]{2}{*}{ Improper/poor handling } & $\begin{array}{c}\text { Rough handling increased meat } \\
\text { temperature } \mathrm{T}_{60 \text { min }} \text { and decreased } \\
\mathrm{pH}_{60 \text { min }} \text { postmortem while had } \\
\text { no significant effect on other meat } \\
\text { quality traits }\end{array}$ & $\begin{array}{c}\text { Rough handling increased plasma } \\
\text { lactate level }\end{array}$ & Pigs & $\begin{array}{l}\text { Gentle (no use of stick or electric } \\
\text { prod, pig not slipping, falling, } \\
\text { nor emitting high-pitched } \\
\text { vocalizations) compared with } \\
\text { rough (where any of these } \\
\text { occurred) }\end{array}$ \\
\hline & $\begin{array}{l}\text { The use of electric prodders } \\
\text { reduced WHC, including increased } \\
\text { drip loss, purge loss, and cooking } \\
\text { loss independent of muscle pH } \\
\text { and temperature; cattle undergoing } \\
\text { electric prodders induced tougher } \\
\text { meat with inferior quality rated by } \\
\text { the consumer panel }\end{array}$ & $\begin{array}{l}\text { The use of electric prodders } \\
\text { increased plasma lactate level }\end{array}$ & Cattle & $\begin{array}{l}\text { Control group (no electric goads } \\
\text { used preslaughter) compared with } \\
\text { stress group ( } 6 \text { prods given with an } \\
\text { electric goad over } 5 \text { to } 10 \mathrm{~min} \text { ) }\end{array}$ \\
\hline Crating & $\begin{array}{l}\text { Crating density had no significant } \\
\text { effects on meat quality or lipid } \\
\text { peroxidation levels }\end{array}$ & $\begin{array}{l}\text { High crating density induced } \\
\text { higher } \Delta \text { rectal temperature, plasma } \\
\text { corticosterone, and heat shock } \\
\text { protein } 70 \text { mRNA levels }\end{array}$ & Poultry & $\begin{array}{c}\text { High }\left(0.0350 \mathrm{~m}^{2} / \mathrm{broiler}\right) \text { compared } \\
\text { with low }\left(0.0575 \mathrm{~m}^{2} / \text { broiler }\right) \\
\text { crating density }\end{array}$ \\
\hline Shackling & $\begin{array}{l}\text { Shackling decreased } \mathrm{pH} 15 \mathrm{~min} \\
\text { postmortem and increased } a^{*} \text { of } \\
\text { breast meat while had no } \\
\text { significant effects on meat quality } \\
\text { traits of thigh meat }\end{array}$ & $\begin{array}{l}\text { Shackling increased glucose, } \\
\text { cholesterol, and heterophil to } \\
\text { lymphocyte ratio. } 120 \mathrm{~s} \text { shackling } \\
\text { induced the highest level of } \\
\text { corticosterone and CK }\end{array}$ & Poultry & $\begin{array}{l}\text { Control group }(10 \mathrm{~s}) \text { compared } \\
\text { with } 30 \mathrm{~s} \text { compared with } \\
60 \mathrm{~s} \text { compared with } 120 \mathrm{~s} \text { shackling }\end{array}$ \\
\hline
\end{tabular}

Ventilation device (Figure 1) contains an air inlet duct 1 equipped with a fan 2 and an electric motor 3 and a water sprayer 4, an air funnel 5 with a control valve 6 and supply air ducts 7,8 with control valves 9 air outlets 10 to a ventilated room 11 with temperature closers 12 , connected by means of a pneumatic lock 13 with an air inlet duct 1 and placed in the soil below the freezing mark of the latter and a program climate controller 14 with temperature sensors 16, 17, 19,20 and speed 15 , humidity 18 , connected to the electric motor 3 of the fan 2 by the control valve 6,9 of the air funnel and supply air ducts 7,8 and the spray 4 and closers 12 of the temperature.
The device contains two supply air ducts 7, 8 to ensure the continuity of the supply of heated air to room 11 while charging one of them.

Assembly and manufacturing of the ventilation device are carried out from prefabricated modular elements selected in accordance with the volume of required ventilation air and the type of agricultural premises.

In the cold period of the year, heavy fresh air flows into the air inlet duct 1 and enters the open-air duct 7 through the airlock 13 , contacts the surface of its walls, is heated by the soil heat 


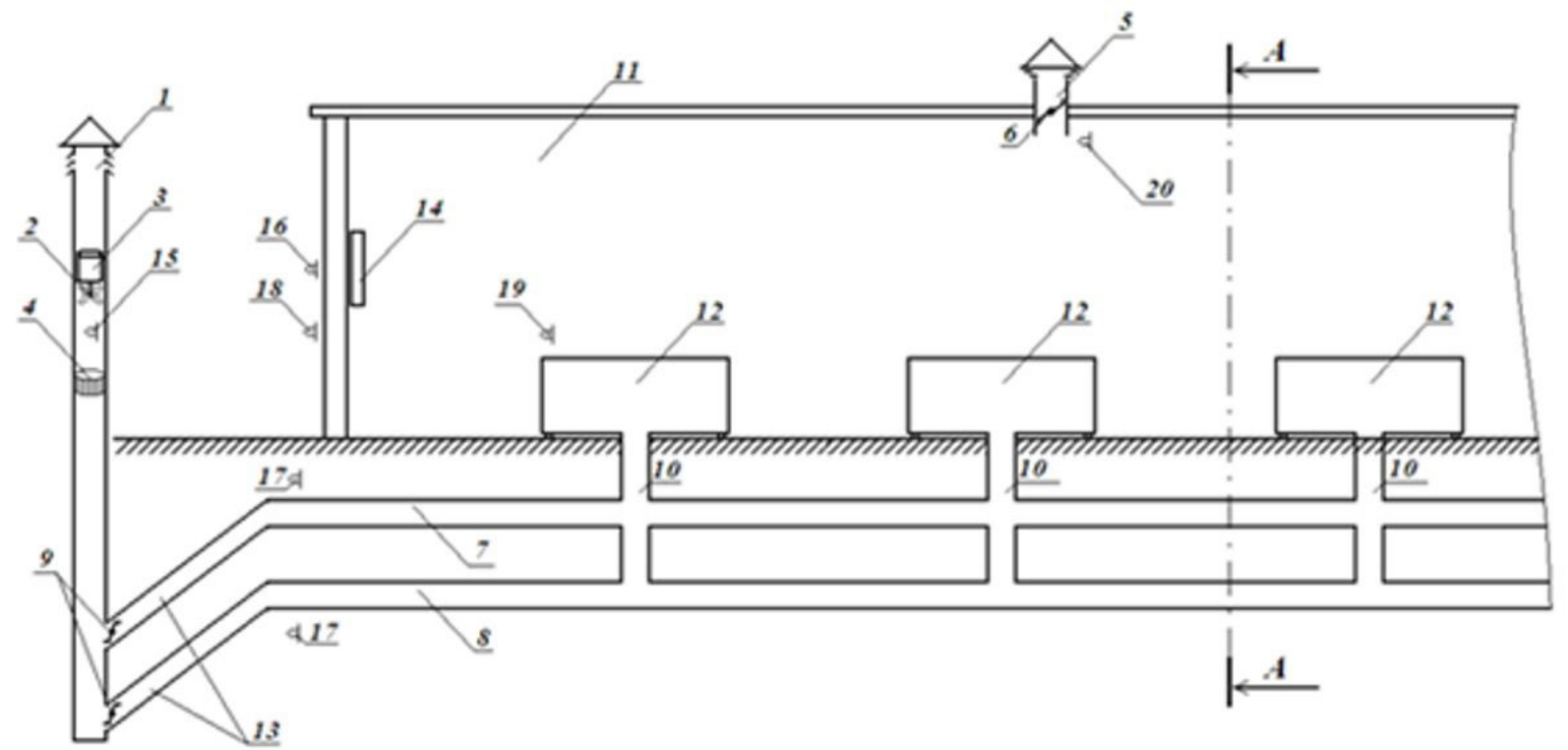

Figure 1. Functional scheme of the ventilation system.

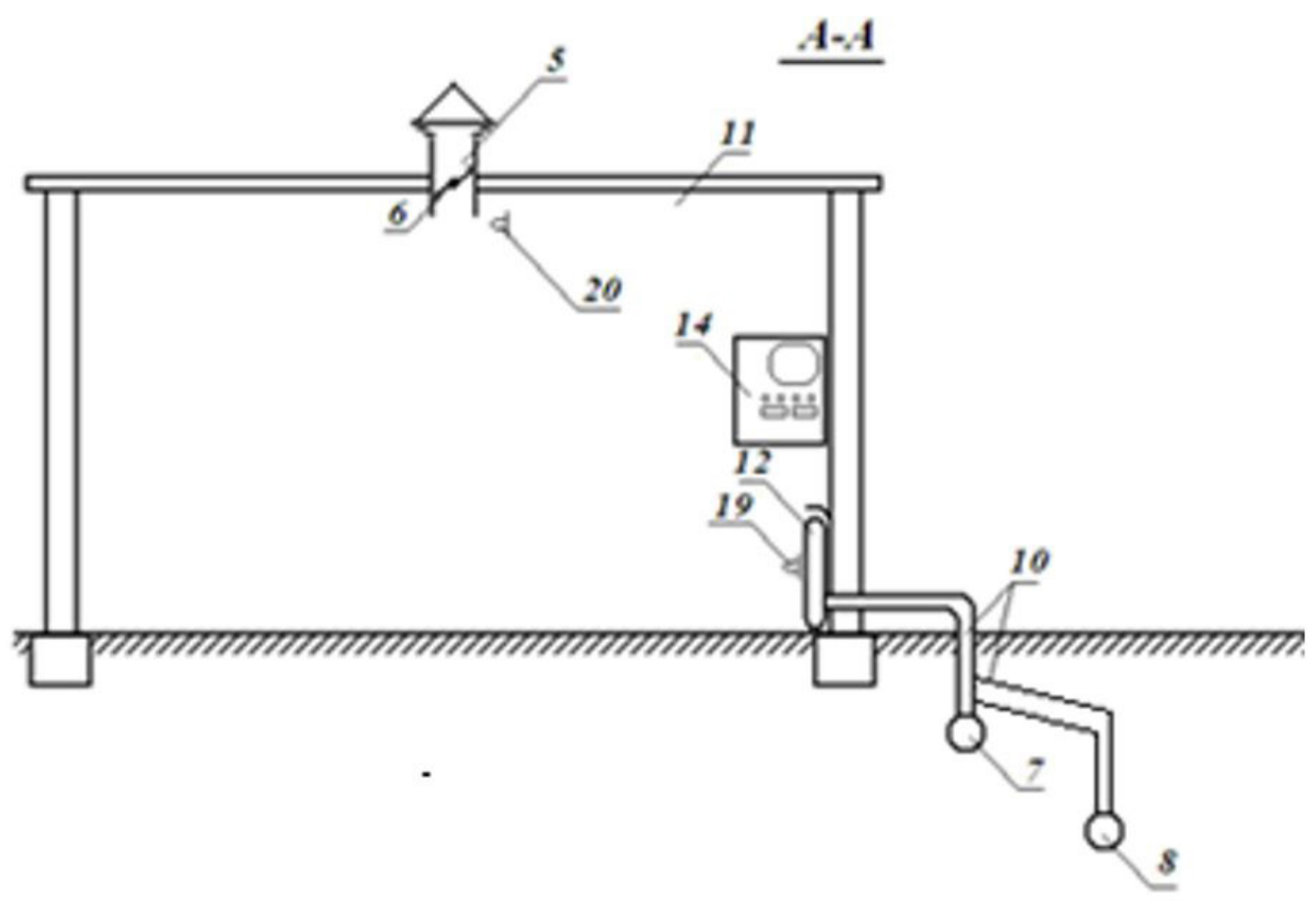

Figure 2. The section on A-A of Figure 1.

and moves up, exits through the outlets 10c room 11, flowing around the temperature closer 12 .

Airlock 13, the threshold of which is located below the bottom of the air ducts 7, 8 does not allow the exit of heated light air from the air duct to the air inlet duct 1 . This ensures strictly one-way gravity movement of fresh air.
The exhaust air is withdrawn from the ventilated room through the air funnel 5 with a control valve 6 controlled by the microclimate program controller 14 .

The program controller 14 controls the operation of the electric motor 3 of the fan 2, which supports the set speed of the gravity flow and the control valves 9 , supply air ducts 7,8 , 


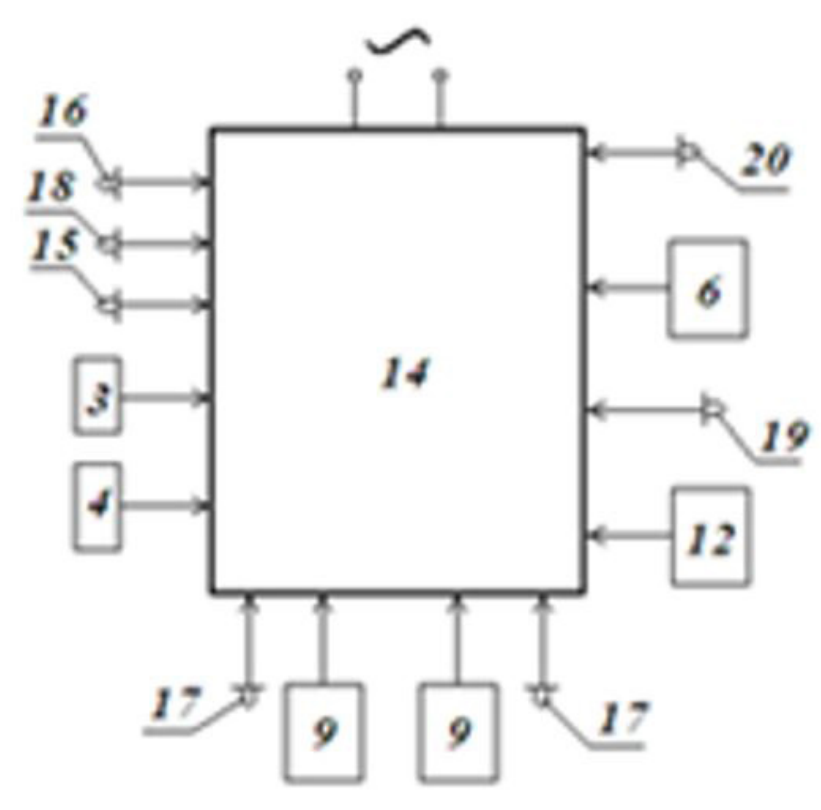

Figure 3. Block scheme of control of the electric motor and control valves of the supply air ducts and air funnel, sprayer, and closers.

providing a set threshold for the temperature of the gravity flow, as well as the temperature closer.

As the temperature of the walls of the air duct 7 or the soil mass decreases, the intensity of heat removal decreases, and at a certain temperature value, the set threshold exceeds the normalized value. At this moment, at the signal of the soil temperature sensor 17, the microclimate controller 14 closes the supply air duct control valve 7 and opens the air duct valve 8 . The soil mass around air duct 7 recovers its natural temperature after a while, i.e., it is recharged, and the soil mass around air duct 8 is cooled, i.e., it is discharged. When the soil temperature reaches the normalized value by means of sensor 17 , the microclimate controller 14 closes valve 9 of the supply air duct 8 and opens valve 9 of the air duct 7 . Thus, the supply air ducts alternately operate in charging and discharging mode and provide a normalized stable supply air temperature, i.e., stabilization.

The heated supply air supplied to the room flows around the temperature closer to 12 , its temperature rises to the normalized value. Enabling and disabling closers is carried out by the microclimate controller 14 via the temperature sensor 19. Closers 12 provide radiant and convective heat exchange in the process of creating a local microclimate.

Valve 6 of the air funnel 5 regulates the outlet of exhaust air, and its operation is controlled by the microclimate regulator 14 by means of a temperature sensor 20 .

As the external temperature increases, the speed of the gravity flow decreases, and at a certain temperature value, the flow rate will be insufficient to provide normalized air exchange. At this moment, at the signal of the outdoor temperature sensor 16 and the flow rate sensor 15 , the microclimate controller 14 connects the electric motor 3 of the fan 2 .

In the warm period of the year, the heated fresh air is pumped by a fan 2 through the air inlet duct 1 into the air duct 7, from where the air enters the ventilated room through outlets 10 . When passing through air duct 7, the heated fresh air is cooled by transferring heat to the soil through its walls. Air ducts 7, 8 will also work in discharge and charging mode during the cold period of the year. Depending on the required humidity parameters of the ventilated fresh air, it is moistened with water through a spray 4.

Sprayer 4 is controlled via the microclimate controller 14 by means of the outdoor humidity sensor 18 and provides the required humidity of the supplied air.

According to this scheme, an experimental energy-saving ventilation system for a sheepfold was designed and built, and production tests were conducted during the lambing period.

\section{Methods of research}

When designing an energy-saving ventilation system, the differential equation of the soil temperature field around the air duct of the ventilation system is considered (Abreu et al., 2021):

$$
\frac{\partial t}{\partial \tau}=a\left(\frac{\partial^{2} t}{\partial R^{2}}+\frac{1}{R} \frac{\partial t}{\partial R}\right)
$$

where $a$ is the thermal conductivity of the soil.

Boundary conditions of Equation 1 are determined by Equation 2:

$$
\begin{aligned}
& t=t_{S} a t 1 . \tau=0 ; 2 . R \rightarrow \infty, \tau \geq 0 \\
& \text { 3. }-\lambda \frac{\partial t}{\partial R}=\alpha\left[t\left(R_{o}, \tau\right)-t_{S}(\tau)\right]=0
\end{aligned}
$$

where $\lambda$ is the thermal conductivity of the soil;

$\alpha$ - coefficient of heat transfer of the channel walls.

Average integral air temperature along the length of the channel with the total heat exchange area $F$ is determined by Equation 3 (Carnovale \& Phillips, 2020):

$t_{a v}(\tau)=\frac{1}{F} \int_{0}^{F} t(x, \tau) d F$

where $t(x, \tau)$ is the local temperature, determined from the heat balance equation of the air duct area $d F$ (Equation 4$)$ :

$c G d t=\alpha\left[t\left(R_{o}, \tau\right)-t(x, \tau)\right] d F$

The solution of Equation 2 has the form given by Equation 5 (Ayantunde et al., 2021): 
$\phi_{x}=\frac{t(x, \tau)-t\left(R_{o}, \tau\right)}{t_{0}-t\left(R_{o}, \tau\right)}=\exp \left(\frac{-\alpha F_{x}}{c G}\right)$

where $t\left(R_{o}, \tau\right)$ - the average length of the channel wall temperature at the time under consideration; $\mathrm{F}_{x}$ - the heat exchange area of the channel to the cross-section $x$.

The solution of the differential equation allowed us to calculate the parameters of the energy-saving ventilation system. A special information and measurement system was developed to record the thermal parameters of the ventilation system, i.e., the temperature of the outdoor, indoor air, soil, and relative humidity of the outdoor and indoor air.

\section{Results and discussion}

The farming industry's transportation is a significant operation. It typically causes stress to the animal and might result in the exhaustion of muscle glycogen stores before slaughter, which raises the meat's final $\mathrm{pH}$ and causes darker meat with a lower expressed juice value (Randall, 1993; Weeks, 2008). temperature and $\mathrm{pH}$ have an impact on meat softness, which is one of the most significant quality attributes. Consumers often use color as a quality indication since it is an essential physical feature of meat. Consumers are becoming more conscious of the ethical issues surrounding meat production, and they prefer meat from animals that have been treated humanely (Jendrisakova et al., 2011). An experimental energy-saving ventilation system was built in a sheepfold for lambing in the Almaty region. The plan and photograph of the sheepfold are shown in Figures 4 and 5.

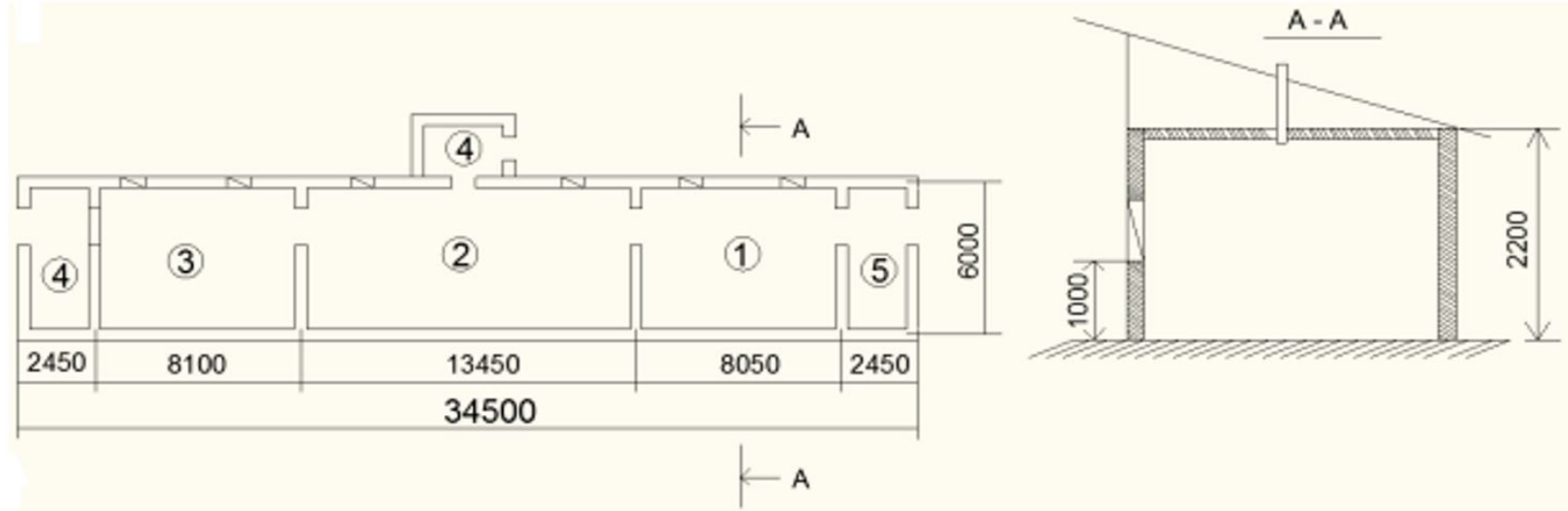

Figure 4. Plan of the sheepfold for lambing; ; 1 - maternity barn; 2 - room for keeping sheep; 3 - room for keeping lambs from 2 months; 4 tambours; 5 - electric board.

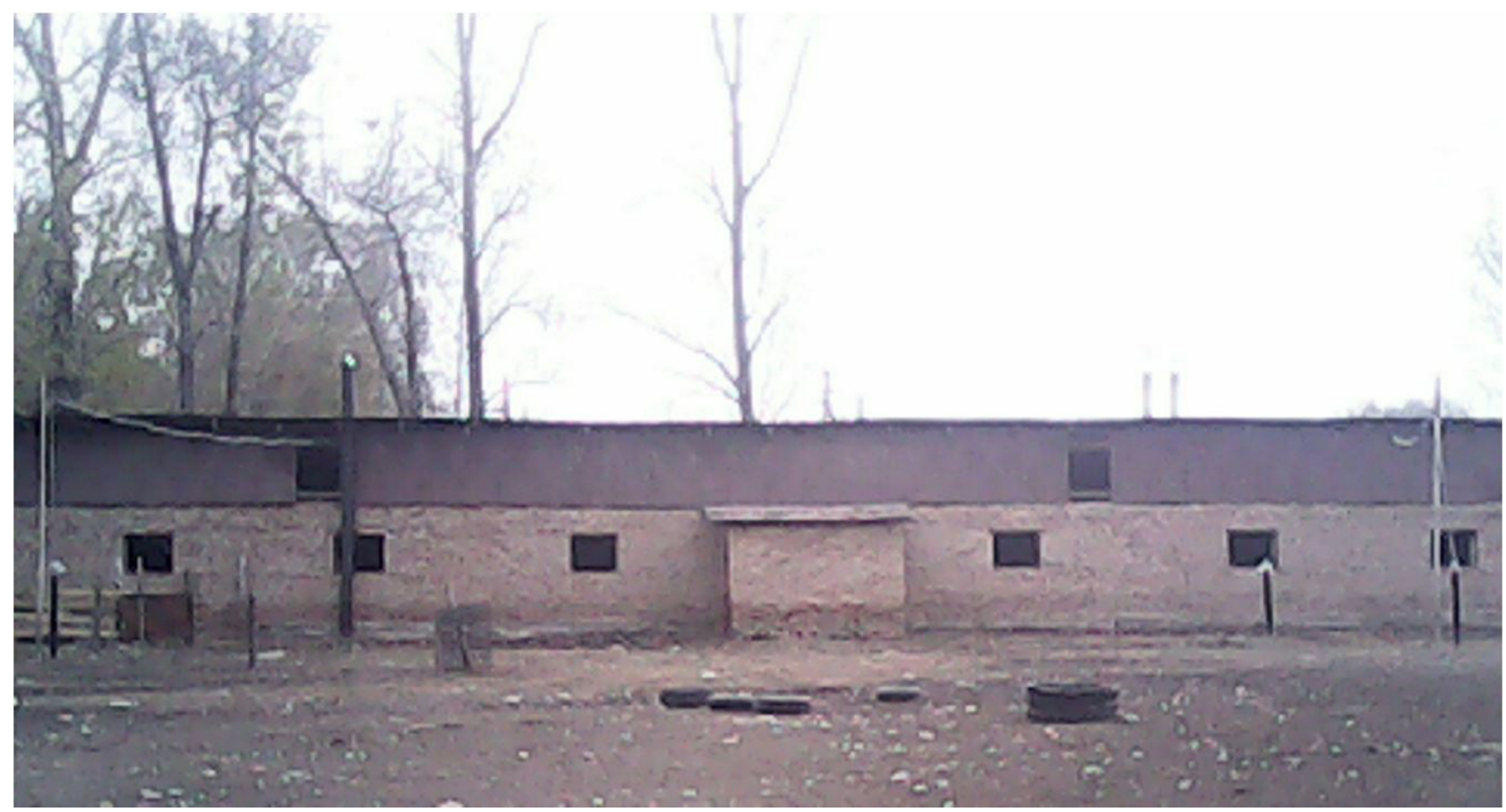

Figure 5. Sheepfold for lambing. 


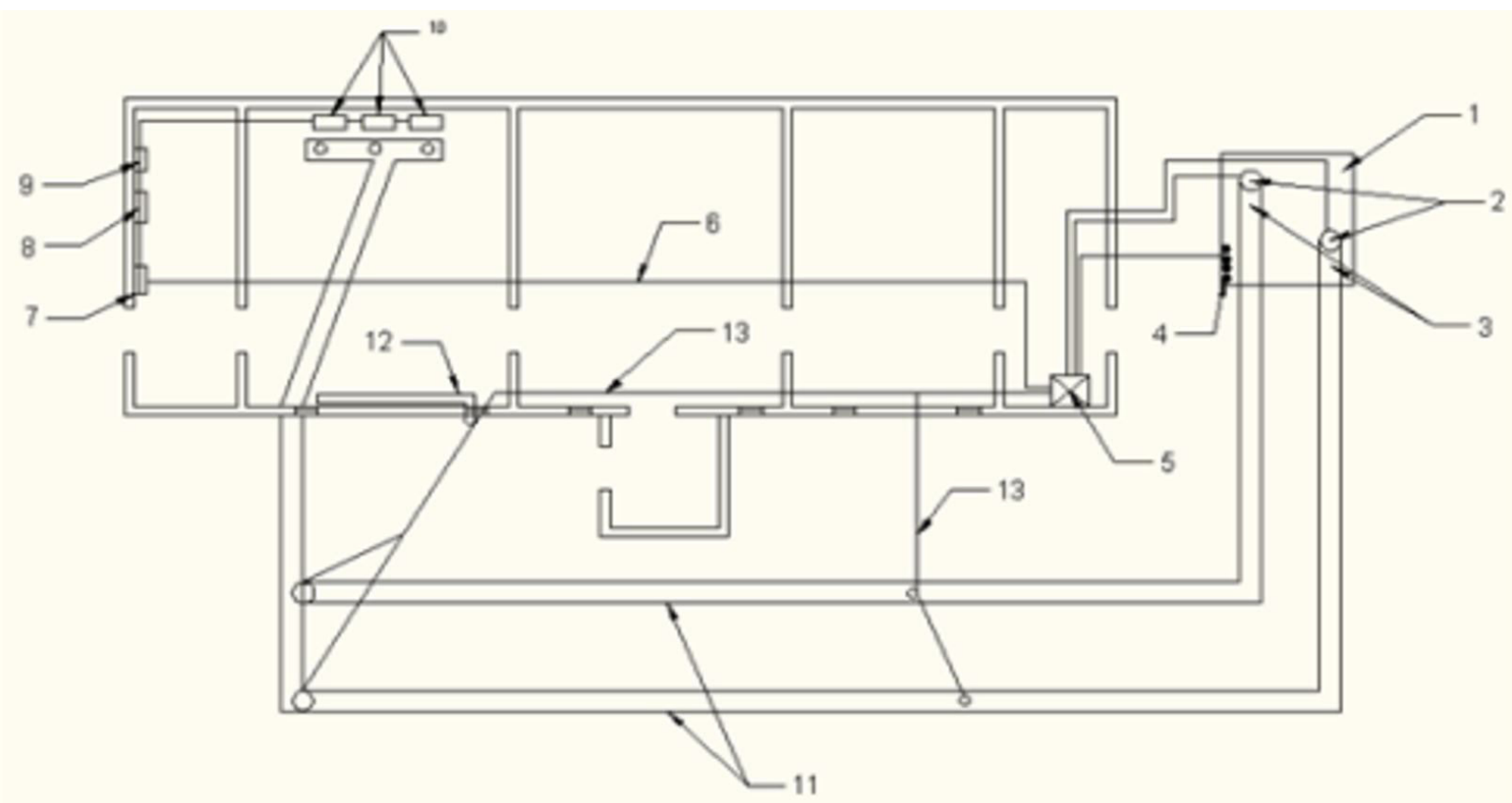

Figure 6. Flow chart of an experimental energy-saving ventilation system for a sheepfold; 1 - room of the air inlet duct; 2 - supply vertical air ducts; 3 - supply horizontal air ducts; 4 - ground temperature sensors; 5 - control cabinet; 6 - power wiring; 7 - power board; 8 - electric meters; 9 - reducing transformer 220/22 V; 10 - closers - electric heating panels; 11 - underground heat exchangers-horizontal air ducts; 12 - air funnel with air duct; 13 - sensor wiring.

The scheme of an experimental energy-saving ventilation system for a sheepfold is shown in Figure 6.

Underground heat exchangers - air ducts were made of corrugated plastic pipes produced by "EPA Almaty" LLP. Pipes are made of high-density polyethylene with nominal internal diameters from $110 \mathrm{~mm}$ to $630 \mathrm{~mm}$. GOST 18599-2001.

Wall profile of the "corrugation" type. The pipes are manufactured with a spigot and socket connection. They are connected via O-ring. They have a hollow structure in the form of hollow channels of a rectangular cross-section perpendicular to the axis of the pipe section, and the inner layer is straight and smooth.

The specially designed outer surface of the pipes has a high ring stiffness and makes them more resistant to compressive loads (transport, soil water, permafrost, and soil compaction), and the elastic structure of the pipes protects them from destruction when exposed to overloads. As a material, highdensity polyethylene has: high tensile strength, high thermal stability, and is not subject to corrosion. Production tests of the energy-saving ventilation system were carried out in two stages: winter and summer.

When testing an energy-saving ventilation system in winter, it was found that the air temperature in the sheepfold premises ranged from $+5.4{ }^{\circ} \mathrm{C}$ to $+6.0^{\circ} \mathrm{C}$, on average $+5.6{ }^{\circ} \mathrm{C}$, with the number of measurements $n=72$.

The relative humidity of the sheepfold premises averaged $79.2 \%$ (at $\mathrm{n}=72$ ). The maximum and minimum relative humidity values were $93.4 \%$ and $64.1 \%$, respectively. At the lowest outdoor temperature $-18{ }^{\circ} \mathrm{C}(04.02 .2014)$, the supply air temperature reached $+6^{\circ} \mathrm{C}$. The flow rate of the supplied air varied between $70-140 \mathrm{~m}^{3} / \mathrm{h}$ depending on the outdoor air temperature. The maximum heat output of the unit was $2.2 \mathrm{~kW}$.

When testing an energy-saving ventilation system in summer, it was found that the air temperature in the sheepfold premises ranged from $+16.6^{\circ} \mathrm{C}$ to $+27.29^{\circ} \mathrm{C}$, on average $+22.3^{\circ} \mathrm{C}$, with the number of measurements $\mathrm{n}=820$.

The relative humidity of the sheepfold premises averaged $30.5 \%$ (at $\mathrm{n}=820$ ). The maximum and minimum relative humidity values were $58.88 \%$ and $10.37 \%$, respectively. At the highest outdoor temperature of $+33.4{ }^{\circ} \mathrm{C}$, the supply air temperature reached $+19.6^{\circ} \mathrm{C}$, and the humidity increased from $12 \%$ to $23 \%$. The flow rate of the supplied air was $140 \mathrm{~m}^{3} / \mathrm{h}$. The cooling capacity of the unit was $2.6 \mathrm{~kW}$.

\section{Conclusions}

Sheep transported for 3 hours in an open truck at $42{ }^{\circ} \mathrm{C}$ may exhibit substantial reactions involving elevated nor-adrenaline, adrenaline, cortisol, and dopamine concentrations (Hall \& Bradshaw, 1998; Knowles et al., 1995). The quality of the meat worsened as well. Low-voltage electrical stimulation of sheep carcasses can help mitigate the negative effects of transportation stress on meat quality. In order to provide safe and quality food, one of the most important aspects of farm animal welfare is to maintain animals clinically healthy, free of disease and stress, especially in intensive breeding. This is a critical problem for the global food business since it is directly related to human health and wellbeing. A mathematical model of heat exchange processes in an energy-saving ventilation system has 
been developed. The ratio of the optimal radius and length of the air duct, the airflow rate of the soil temperature, and the volume of heat in the ventilation system are determined. The technological, functional, and concept schemes of an energy-saving ventilation system have been compiled. The parameters of a ventilation system for a sheepfold using soil heat were determined.

Production tests of an experimental modular energy-saving ventilation system were carried out in two stages: winter and summer. Registration of thermal parameters of the ventilation system was performed remotely using the MasterScada system.

Assessment of the technical and economic efficiency of the work performed shows that energy consumption is reduced by up to $40-50 \%$ when implementing an energy-saving ventilation system, depending on the type of agricultural premises.

During the testing periods, the energy-saving ventilation system provided the energy-saving mode and the required zootechnical parameters of the microclimate in the maternity barn of the sheepfold. The energy-saving ventilation system was adopted for economic use and recommended for implementation in sheep farms.

\section{References}

Abreu, K. S., Guim, A., Carvalho, F. F., Ferreira, M. A., Monnerat, J. P. I. S., Fernandes, J. V., Lima, A. C., Santos, C. C., \& Silva, J. F. No. (2021). Effects of additives in wet brewery residue silage on lamb carcass traits and meat quality. Tropical Animal Health and Production, 53(1), 85. http://dx.doi.org/10.1007/s11250-020-02531-z. PMid:33411085.

Ayantunde, A. A., Salifu, S., Konlan, S., \& Dembele, T. (2021). Feed and health package for improved small ruminant production. Retrieved from https://cgspace.cgiar.org/bitstream/handle/10568/112912/ Feed\%20and\%20health_Final_WEB.pdf?sequence=5.

Baljić, R., Gazibera, B., Gojak, R., Lukovac, E., \& Mulabdić, V. (2019). A family outbreak of foodborne botulism following consumption of smoked meat in Sarajevo, Bosnia and Herzegovina. Medical Journal, 25(3/4), 85-87.

Carnovale, F., \& Phillips, C. J. (2020). The effects of heat stress on sheep welfare during live export voyages from Australia to the Middle East. Animals, 10(4), 694. http://dx.doi.org/10.3390/ani10040694. PMid:32316242.

Costa, R. G., Cavalcanti, M., Nobre, P. T., Queiroga, R. C. R. E., Medeiros, G. R., Silva, N. V., Batista, A. S. M., \& Araújo, J. T. Fo. (2020). Sensory quality of meat from Santa Inês lambs fed with guava (Psidium guajava L.) agroindustrial by-product. Food Science and Technology, 40(3), 653-658. http://dx.doi.org/10.1590/fst.14419.

Gali, A. U., Abdullahi, H. A., Umaru, G. A., Zailani, S. A., Adamu, S. G., Hamza, I. M., \& Jibrin, M. S. (2020). Assessment of operational facilities and sanitary practices in Zangon Shanu abattoir, Sabon Gari Local Government Area, Kaduna State, Nigeria. Journal of Veterinary Medicine and Animal Health, 12(2), 36-47. http://dx.doi. org/10.5897/JVMAH2019.0756.

Grandin, T. (2021). Methods to prevent future severe animal welfare problems caused by COVID-19 in the pork industry. Animals, 11(3), 830. http://dx.doi.org/10.3390/ani11030830. PMid:33809412.

Hall, S. J., \& Bradshaw, R. H. (1998). Welfare aspects of the transport by road of sheep and pigs. Journal of Applied Animal Welfare Science, 1(3), 235-254. http://dx.doi.org/10.1207/s15327604jaws0103_4. PMid:16363968.

Ibidhi, R., \& Salem, H. B. (2019). Energy footprint assessment of sheep meat produced under two different farming systems in Tunisia.
Options Méditerranéennes. Série A: Séminaires Méditerranéens, 123, 247-251.

Jendrisakova, S., Kovacikova, Z., Vargová, V., \& Michalec, M. (2011). The impact of cattle and sheep grazing on grassland in Vel'ká Fatra National Park. Journal of Water and Land Development, (15), 83-90.

Knowles, T. G., Brown, S. N., Warriss, P. D., Phillips, A. J., Dolan, S. K., Hunt, P., Ford, J. E., Edwards, J. E., \& Watkins, P. E. (1995). Effects on sheep of transport by road for up to 24 hours. The Veterinary Record, 136(17), 431-438. http://dx.doi.org/10.1136/vr.136.17.431.PMid:7631478.

Leonte, D., \& Leonte, C. (2020). Some aspects regarding the storage of foodstuffs in food profile units. Lucrări Științifice, Seria Zootehnie, 73, 213-217.

Moberg, E., Säll, S., Hansson, P., \& Röös, E. (2021). Taxing food consumption to reduce environmental impacts-Identification of synergies and goal conflicts. Food Policy, 101, 102090. http://dx.doi. org/10.1016/j.foodpol.2021.102090.

Nenadović, K., Čobanović, N., Vučinić, M., Bugarski, D., Mikuš, T., Voslarova, E., Zupan-Šemrov, M., Kjosevski, M., \& Karabasil, N. (2021). Welfare and meat quality of lambs. Veterinarski Glasnik, (00), 1-13. http://dx.doi.org/10.2298/VETGL210126006N.

Onopiuk, A., Kołodziejczak, K., Szpicer, A., Wojtasik-Kalinowska, I., Wierzbicka, A., \& Półtorak, A. (2021). Analysis of factors that influence the $\mathrm{PAH}$ profile and amount in meat products subjected to thermal processing. Trends in Food Science \& Technology, 115, 366-379. http://dx.doi.org/10.1016/j.tifs.2021.06.043.

Phillips, C. (2019). Transport of cattle, sheep and other livestock by sea and air. In T. Grandin (Ed.), Livestock handling and transport. Wallingford: CABI.

Ponnampalam, E. N., Dunshea, F. R., \& Warner, R. D. (2020). Use of lucerne hay in ruminant feeds to improve animal productivity, meat nutritional value and meat preservation under a more variable climate. Meat Science, 170, 108235. http://dx.doi.org/10.1016/j. meatsci.2020.108235. PMid:32688224.

Randall, J. M. (1993). Environmental parameters necessary to define comfort for pigs, cattle and sheep in livestock transporters. Animal Science, 57(2), 299-307. http://dx.doi.org/10.1017/S0003356100006929.

Rice, M., Hemsworth, L. M., Hemsworth, P. H., \& Coleman, G. J. (2020). The impact of a negative media event on public attitudes towards animal welfare in the red meat industry. Animals, 10(4), 619. http:// dx.doi.org/10.3390/ani10040619. PMid:32260202.

Soni, A., Kumari, S., \& Gadekar, Y. P. (2021). Quality control for hygienic mutton production. In V. Kadam, A. S. Phand \& A. Kumar (Eds.), Sheep wool and mutton: production and value addition (pp. 56-63). Hyderabad: ICAR-CSWRI.

Stahlke, E. R., Rossa, L. S., Silva, G. M., Sotomaior, C. S., Pereira, A. J., Luciano, F. B., Borges, T. D., \& Macedo, R. E. F. (2019). Effects of modified atmosphere packaging (MAP) and slaughter age on the shelf life of lamb meat. Food Science and Technology, 39(2), 328-335. http://dx.doi.org/10.1590/fst.29617.

Tsakiridis, A., O’Donoghue, C., Hynes, S., \& Kilcline, K. (2020). A comparison of environmental and economic sustainability across seafood and livestock product value chains. Marine Policy, 117, 103968. http://dx.doi.org/10.1016/j.marpol.2020.103968.

Warriss, P. D. (2020). Antemortem factors influencing the yield and quality of meat from farm animals. In S. D. M. Jones (Eds.), Quality and grading of carcasses of meat animals (pp. 1-15). Boca Raton: CRC Press. http://dx.doi.org/10.1201/9781003068297-1.

Weeks, C. A. (2008). A review of welfare in cattle, sheep and pig lairages, with emphasis on stocking rates, ventilation and noise. Animal Welfare, 17(3), 275-284. 